\title{
The Ethical Dilemma in Globalising Small Businesses
}

\author{
Jacob C. Ng'ang'a
}

\begin{abstract}
This paper is largely a theoretical exposition of ethical challenges that stifle the participation of small businesses in the global value chains with particular reference to businesses in developing countries. Smallbusiness clusters in developing economies, remain locked in low-quality products and low-income markets. With little innovation, small business lack capacity to produce goods that can attract foreign demand. Yet, small enterprises must provide productive employment for an increasing number of job-seekers in these countries. Innovation growth in small enterprises is normally limited to apprenticeship process and as such, results in a dead-end to progress of indigenous technology. To promote creation and growth of small business, efforts are required to put the small business clusters in a global value chain as this enhances possibilities of new market avenues and as well as benching market indigenous innovative efforts to international standards. Exposure of small business to global market also encourages networks formations which are conduits of skills for quality improvement and valuation of products from the sector. However, the quest for improving the participation and market share of small business is faced with challenges that stem from the way the process of globalization has taken place over time. To overcome these globalization challenges, policy makers must contend with ethical issues that require to be addressed through consultative efforts at international arena.
\end{abstract}

\section{Key words}

Small business, globalization, ethics, networks, value chain.

\section{Introduction}

While there are many definitions of globalization, one may take note of the words of Held et al (1999) which suggest that the concept of globalization implies, first and foremost, a stretching of social, political and economic activities across frontiers such that events, decisions and activities in one region of the world can come to have significance for individuals and communities in distant regions of the globe (p.15). Nevertheless, the actors in social, political and economic arena impact on global development only if barriers, tariff and non-tariff, that make nations exist as exclusive enclaves are removed. Thus, this

Copyright (C) 200x Victoria University. This document has been published as part of the Journal of Business Systems, Governance and Ethics in both online and print formats. Educational and non-profit institutions are granted a nonexclusive licence to utilise this document in whole or in part for personal or classroom use without fee, provided that correct attribution and citation are made and this copyright statement is reproduced. Any other usage is prohibited without the express permission of the publisher. paper takes globalization as a term used to describe a situation where there are reduced barriers to information flow, international trade, foreign investments, technology development and transfer, human resource mobility and democratic choice.

Small businesses play a significant role in world economies, contributing substantially to employment creation in developing economies and to exports in South East Asia (UNCTAD, 2004). However, the globalization process 
constitutes challenges and opportunities to small businesses. For instance, globalization brings new opportunities for small businesses due to increased access to new markets and wide knowledge based on technology developments (Goldin, 2010). However, ethical issues are now emerging in relation to how globalization affects the operations of small businesses within economics, social relations, politics, media and technology contexts (Stephens 2011, Lyons 2005). In discussing these issues, this paper conceptualizes ethics as principles and practices that morally affect our decisions in the ordinary business of life. Ethical behavior in a globalization process therefore relates to fairness in interpersonal and intergroup interactions that maximizes the gains for all participants.

\section{Ethical issues on how Globalization influence Economic Performance of Small Businesses}

One cornerstone of the globalization process is market liberalization which emphasizes removal of all tariff and non tariff barriers to product and resources mobility, including elimination of all impediments to competitive practices in economic activities (Cornia, 1999). Those who advocate for liberalization argue that on the supply-side, small businesses will benefit through better access to efficient technologies and cheaper raw materials ${ }^{2}$. Consequently, small business would optimally allocate resources and enjoy scale economies which will ultimately bring new employment opportunities and better incomes for a country's citizens. On the demand-side, market liberalization enables business to get "vent-for-surplus" since removal of tariffs widens market from within-the-country boundaries to the global arena.

The ethical issue that arises within this context is embedded in the assumption implicit in the theoretical foundation of market liberalization. What is assumed is that market liberalization improves both productive and allocative efficiency of a firm arising from competition among economic units (Cornia, 1999, Goodhue et al, 1998). What then can be construed from the assumption is that any existing small business possesses a competitive edge which makes it thrive in a liberalized world of perfect knowledge and free resource mobility. However, small businesses in different economies face varying constraints due to different business environments influenced by the level of development and the policy setting of a country (Haltiwanger, 2011). Further, the entry of any business to global market is subjected to laws, regulations and quarantines in the form of the entry permits (Greenaway et al., 2008) but excessive operational restrictions overly oppress small business, make it difficult for it to take advantage of global market opportunities.

Small businesses in Less Developed Countries (LDCs) face inherent problems that make them globally uncompetitive. First, they have resource limitations in term of physical resources, skill competencies and technology (Hussain et al., 2012). Further, information flow is costly and not choice-free as small businesses are characterized by ineffective networks (Ng'ang'a, 2008). Some small businesses sometimes have the know-how but lack resource capacity to drive the innovative idea to other stages of product's value chain (KIPPRA, 2009). As Pierre-Andre (1996) observes, globalization bring along it "complexification" of production systems which can be detrimental to small businesses since they do not have the enormous resources of multinational businesses to adjust to the increased competition in a globalized environment. Pierre-Andre (1996) further notes that globalization brings forth intense competition and shorter life cycles of products, resulting in high mortality of businesses, reduced employment and increased incidences of poverty in LDCs. Thus, even if globalization allows wider product choices to consumers in LDCs, small businesses may be driven out of market by big foreign

\footnotetext{
${ }^{2}$ See IMF issue brief No. 08/02 - May 2008 on IMF's work on globalization http://www.imf.org/external/np/exr/key/global.htm
} 
firms or through flooding of cheaper import substitutes (Ahmad and Shamsudin, 2008). Failure of local firms in any economy finally results in reduced incomes creating of a consuming society without means to consume. For instance, it is not a surprise to watch an African child wearing a shirt with a label "Coca Cola enjoy" but queuing for food donation. Is it ethical to enrich businesses in developed world at the expense of businesses and individuals in developing economies? Is globalization a gospel of prosperity or death to small businesses in third world countries?

Another fundamental ingredient of globalization is privatization of public corporations. As Goodhue et al (1998) mentions, market liberalization and privatization are considered to complement each other in a transition economy. Farazmand (2002) argues that privatization is not a haphazard phenomenon but a deliberate design of globalization of capital. Public enterprises in most LDCs are characterized by excess capacity production of low-quality products and inefficient costing (Republic of Kenya 2010). This is normally attributed to lack of profit-motive which makes the public businesses not to strive for competitive performance. Competition is healthy for the economy as it leads to cheaper high-quality products and wider consumer choices. Thus, bilateral and multilateral agencies encourage LDCs to privatize their public corporations so that resources are efficiently utilized, creating new employment opportunities in a competitive environment.

The ethical issues that arise here is not so much on the validity of theoretical exposition of privatization benefits but on public versus private ownership of wealth. The first concern is whether all public businesses should have profit-goal orientation. If not, how do we then compare performance of private and public enterprises? The other issue to consider is the redistribution of wealth that emanates from the privatization process. Assuming an efficient system of governance, the proceeds from public enterprises should be used for public goods or utilities. Individuals own private enterprises and the benefits thereof. Is it ethical to redistribute wealth from public ownership to individual persons in the privatization process? Beyond the wealth distribution issue, small businesses may require government protection in the infancy stage as an incubation process. The quest for reducing direct government participation in economic activities therefore compromises the government capacity to support emerging small businesses.

The possibility of redefining the goals of public corporations and then re-structuring the management should be explored. Moreover, a worrying trend is that most of the public enterprises are being sold to multinational corporations that out-compete locally owned small enterprises. Local resources, particularly through savings and credit schemes, can be redirected to ownership of privatized public corporations. Thus, governments of LDCs should question the rationale for, and the approach they take in, privatization.

\section{Understanding the Social Context of Small Business in a Globalization Process}

Global economy has evolved as result of interplay of a complex set of social, ecological and cultural developments that have direct impact on human and natural resources (Stohl, 2001). For instance, globalization raises global incomes due to enhance market outlets but redistributes income occasioned by resource mobility. Consequently, the focus on globalization should not only be on profit-making, but also on how to balance economic growth with equity. Perceiving the world as a global village hosting more than six billion members, ethical principles would aspire for practices that facilitate equal opportunity to access and utilization of resources for each member of human race. The very fact that the world is divided into continents with differing morphological compositions negates the postulate of equitable distribution of the natural resources. The geographical zones endowed with better natural resources like minerals and arable lands are likely to have higher concentration of wealth based on utilization of available resources. 
The ethical question that arises therefore is whether a mechanism exists that promotes equitable allocation of resources amongst the nations, regions and individuals of the world. Naturally, sections of world population with financial and technical capability exert control over the limited resources. Further, the natural distribution of population across nations and regions with distinct cultures presents patterns of resource distribution pegged along levels of education, health, wealth and skill competencies. For a small business in a developing country with no scale economies to its advantage, market liberalization pushes it into the periphery of resource ownership. Access to global resources is likely to be riddled with biases and prejudices against businesses that cannot competitively survive in a globalized world, which in turn impinge on what is ethical and what is practical.

Assuming that morality is the basis of individual ethics, perception on what is moral among the world population differs from faith to philosophy, resulting in never-ending lists of irresolvable concerns (Robertson, 1992). In such a context, it is difficult to define what is morally acceptable to guarantee fairness in global markets. At global level, ethical behavior should pursue codes of practice which charge every individual with responsibility for their actions, and applications of standards that protect against infringing of other people's value systems. Ultimately, a universal code of ethic should strive for fair practices that disregard race, gender or class. Where ethical question point to the wrong decisions that have been made, such developments should be used as learning experiences and give direction on global interventions for a fair and just systems all over the world.

Business development agencies focus on the small businesses only as just hatcheries for large enterprises, with firm size influencing the business strategies in market expansion and product breadth (Hoang, 1998). This view misses the reality of emerging small businesses in developing countries. Small businesses in developing economies sometimes define the very essence of life to the entrepreneurs, since the businesses are the only available means of livelihood. For instance, a general observation of small businesses in Kenya shows that there are an increasing number of informal enterprises which, in most cases, stem from the need to escape from the joblessness and starvation facing desperate and unemployed people. Therefore, the question of who becomes an entrepreneur goes beyond entrepreneurial traits of opportunity identification and risk taking. The small business may define the very essence of an entrepreneur's existence and not McClelland's (1961) perception of "needs achievement" activity. In trying to develop an entrepreneurial culture in a population, analysis of what motivates a potential entrepreneur should contextualize the grounds that drive the need for self-employment. Brockhaus (1982) argues that the need for independence and control is a transitional step in overcoming odds. For this reason, internal locus of control positively correlates with business success which then becomes a symbolic and emotional reality for the small business owner. Therefore, participation of small business in a global value chain is a global human right issue.

Schumpeter (1934) explains that upsurges in the level of small business start-ups are an indication of labor market turbulence. Thus, self employment is especially strong for individuals who do not have other opportunities of achieving social distinction. Where the market does not guarantee such opportunities, struggle for survival leads to unethical means of self-employment that include drug trafficking ( its spillover effects is now a global problem) and commercial sex workers (addressing the HIV infection is a burden to world population health budgets). The small business owner consequently faces challenges of labor productivity arising from unhealthy labor force.

\section{The influence of Political Globalization on Small Business Performance}

Political globalization may be perceived as a process that works to put the 'global village' in a system based on democratic principles. Democracy is taken to mean 'the rule of the people by the people for the 
people' ${ }^{3}$. Theoretically, globalization promotes democracy in the sense that market liberalization precipitates clamor for free flow of information, openness of state institutions, an end to corruption and the application of the rule of law and order (Richard, 1995). However, from a general observation of countries where liberal democracy is practiced, one notices that people do not rule themselves as the principles of democracy state, but instead a small number of influential people exist within the community to rule the majority. This small group has immense wealth which they use to control resources and media, thereby entrenching their political power. Democracy becomes the relevant and easier way to rule directly or through proxies. Subsequently, the small group of ruling elite increases its wealth and mid-wife reforms to perpetuate themselves in power. This perspective of political development, particularly observable in Africa, mirrors what Hyden (2003) calls neo-patrimonialism, that is, the use of public resources for private economic or political gains. As Stephens (2011) notes, since early 1980s many African dictators have held sham elections to transform themselves into 'democratic leaders,' for purposes of getting aid and receiving international recognition, but cunningly used the colossal debts to entrench themselves in power. In the long run, conflicts arise between groups in 'democratized' economies, between the winners (the ruling class) and the losers (the general population).

Meanwhile, the ruling elite portray economic inequality-based conflict as conflict arising from differences in race, tribal, culture, religion or political parties ${ }^{4}$. Reality on the causes of social upheavals therefore becomes blurred. Within this environment, small businesses are affected in either one of the two ways. Small businesses associated with the ruling party/group gets fiscal support (financial or otherwise) and later use part of their proceeds to strengthen the ruling party or group to stay in power (Hyden, 2003). The other group of small enterprises hardly gets any support from the government but are subjected to "regulations" to steer them away from pursuing growth that threaten the benefits of multinationals or industries owned by the members of ruling group.

\section{Ethical Aspects in Technology Development for Small Business in Global context}

A close scrutiny of transfer, and acquisition, of technology to the small-business sector reveals crucial ethical aspects that demand attention if the sector is to play a significant role in the emerging global market. One ethical issue touches on price. Beyond capturing the value of a technology as a product, pricing may be designed to keep out a certain category of potential users, scaling down competition from emerging businesses (Gürak, 2003).

The second ethical issue is the patents rights given to innovators to help them recover costs of research and development related to a particular technology. Obviously, a patents system stimulates innovative activities since research efforts get rewarded. However, no standard criteria exists for defining the time period applicable to a patent except for estimation of a time interval long enough for the innovating entity to recoup the costs. Thus, there could be cases where long periods are embedded in patents rights given to technology innovators such that by the expiry of most patents, the technology may be obsolete and information asymmetry may result in small businesses purchasing such technologies.

The third ethical issue relating to technology transfer to small businesses is the appropriateness of such technology. Technology is mostly developed by large enterprises in the developed world, mostly by multinational corporations, and is oriented to overcoming resource constraints faced by these enterprises

\footnotetext{
${ }^{3}$ The origin of this definition is explained by Mubangizu: http://www.ajol.info/index.php/ldd/article/viewFil

${ }^{4}$ The 2008 post election violence in Kenya depicted this pattern where members of particular tribes were attacked as deemed beneficiaries of skewed allocation of public resources
} 
(Archibugi et al, 2002). Most small businesses in developing countries face an entirely different set of constraints. For instance, whereas high labor costs is a challenge to manufacturers in developed economies, low-cost labor is the competitive advantage that is potentially available to small businesses in LDCs (Wang et al, 2010). Indeed, for these small businesses, the advanced technology available in a global market is inappropriate in the sense that what is useful to them is intermediate technology that makes labor more productive.

The fourth ethical issue is the medium of technological transfer from large enterprises to small businesses. Technology transfer is cost-effective and efficient if networking linkages exist between the two categories of businesses. Previous empirical works show that such linkages do not exist in many LDCs (Ng'ang'a, 2008). This calls for technology policy formulation that promotes sub-contracting arrangements between small and large businesses in developing countries. Gürak (2003) summaries the predicament that face smost LDCs in technology transfer when he notes that "a country with low technological absorptive capacity would not know what alternative technologies are available, what are the most suitable ones for local production, what the best channels of transfer are and how to bargain effectively about the terms of transfer"(pg 10).

\section{Role of Global Mass Media in Growth of Small Businesses}

The globalization of mass media may potentially influence the performance of small businesses in developing economies. One ethical aspect of media that affects small businesses in global context is the control of information. The global mass media controls the information the world receives (Gerbner et al, 1986). Therefore, wire agencies such as Reuters and Agence France-Presse (AFP) are likely to determine what the print media is to receive while the leading global broadcasters such as CNN, BBC, and ITN dominate what the entire world watches daily. Lyons (2005) observes that since the global media houses are basically profit-oriented, it is the advertising from multinationals contracts that punctuate all broadcasts from these global mass media. Issues that relate with small businesses are therefore in periphery in global attention and limited to documentary coverage of isolated cases of unique innovations. Beyond inadequate coverage in global media, global advertising skews the markets against products from small businesses. As Lyons (2005) rightly notes, the global mass media has enormous influence on consumer tastes and preferences, particularly when an advertisement is conveyed over and over again. When a message such as "mothers who care use product $X$ " from a certain multinational corporation is transmitted more than a thousand times on radio, television and newspaper each year, the tendency is for consumers to religiously belief the message. The ethical issue here is that the products made by small businesses are consequently viewed to have little or no value in comparison to products promoted by the global mass media.

The high costs of advertising ${ }^{5}$ in the global mass media compromise the competitiveness of products from small businesses. The costs of placing an advertisement in the global mass media is out of reach for small businesses. The expenses incurred even in one advert may be many times more than the annual sales revenue of many small businesses. Global consumers therefore are probably not aware of the products of such businesses as these products rarely feature in the media.

The media paves the way for acceptance of a certain way of doing things (Strelitz, 2004). Consequently, the global mass media has developed as a custodian of the global culture. Through advertisements in global mass media, culture and values of Western Europe and United States are exported to the rest of the world. Given that ownership of major media houses and multinational corporations is more concentrated

\footnotetext{
${ }^{5} \mathrm{http} / /$ expenditurereport.warc.com/MediaCostData.aspx
} 
in few western countries, global media tend to convey that only products that originate from certain economies are of the quality, specifications and standards that are internationally acceptable. The ethical issue in this respect is that small businesses' products are always seen as unacceptable in cultures outside the economies where they are produced.

With domination of media houses in Europe and U.S.A in global mass media, the packaging of news coverage from different areas of the world may deliberately distort market information on products produced on those countries. For instance, global media houses are often awash with news from Africa relating to famine, drought and political upheavals ${ }^{6}$. Rare coverage of wild Africa showing richness of the continent in wild animals complements the news coverage. To global audience, such news portrays Africa as underdeveloped continent prime for minerals exploration, tourism (for risky adventures) and for recording documentaries such as "survival" and "hunger from Horn of Africa". Any product from such a continent must pass "standardization criteria of imports to the European Union" ". Similarly global media often report on labor and human rights violations in China and a couple of South American countries with alluded implication that purchase of products from those countries is propagation of those violations ${ }^{8}$.

With no international code of ethics that binds all journalists and media houses to adhere to what is ethical, the global mass media actions are guided by what they consider as relevant and in the interests of the client investors. As long this is the sole criteria, the ethical issue is how to sensitize the world on small businesses so that the sector grows to a level it can fairly competes with relatively large enterprises in global market.

\section{Conclusions and Policy Recommendations}

The Globalization process affects the extent to which small businesses improve welfare through employment creation and income generation. Moving towards a globalized economy brings forth ethical challenges that affect the performance of small businesses. Removing trade barriers and privatizing public corporations make small businesses compete against foreign firms and influx of cheap imports. Similarly, resource and income distribution are skewed against small businesses in a global context. The poor linkages between multinationals and small businesses in developing countries hamper technology transfer between the two. Unable to influence the global media, market access to products from small businesses is a challenge.

In drawing lessons on how globalization process can be harnessed to promote participation of small businesses in global value chain, this paper revisits Michael Porter's Diamond Model. Porter (1990) suggests that improving the competitiveness of a business requires interventions in four areas, namely the factor conditions, demand conditions, related and supporting industries and business strategies, structure and rivalry. In this study, Porter's Diamond Model is reconstructed in the context of small business's position in the global value chain. To overcome ethical challenges, in economic, social and political spheres, that limit enterprise performance in a globalized environment, small businesses must work on their internal contexts to improve their competencies. This will complement inventions by other institutions to improve demand and supply conditions facing small businesses.

\footnotetext{
${ }^{6}$ This can be verified by sampling news on, say, Africa from major media houses on any given day

${ }^{7}$ http://www.cen.eu/cen/Pages/default.aspx

${ }^{8}$ https://www.chinabusinessreview.com
} 
Figure 1 illustrates the initiatives that a small business can use to strengthen its competitive edge in a global market. For instance, to upgrade their performance, small businesses must take stock of their innovations and seek intellectual property protection. The ownership of production rights over a technology is a competitive edge that strategically enables the innovator some reasonable market power in transactions relating to the technology. Similarly, for effective technology transfer, skilled manpower training is the key to successful application, adaptation and further development of technology imported from developed to developing economies. Individual businesses should therefore closely work with government institutions through, say, public-private partnership for curriculum development and provision of training facilities. Further, innovative activities are driven by needs assessment of consumers' tastes and preferences. Therefore, it is the indigenously grown and local-developed technology that will capture the technological needs of local industrialization. Innovators in the industrial world are unlikely to be aware of technological gaps in LDCs.

In light of ethical issues raised earlier over global mass media, coverage of local innovations and small business products in global media requires that either the donor agencies or respective national government foot the bill of advertisements, since very few small businesses are likely to afford such advertisements.

\section{Figure 1: Improving the Participation of Small Business in Global value chain: the Diamond}

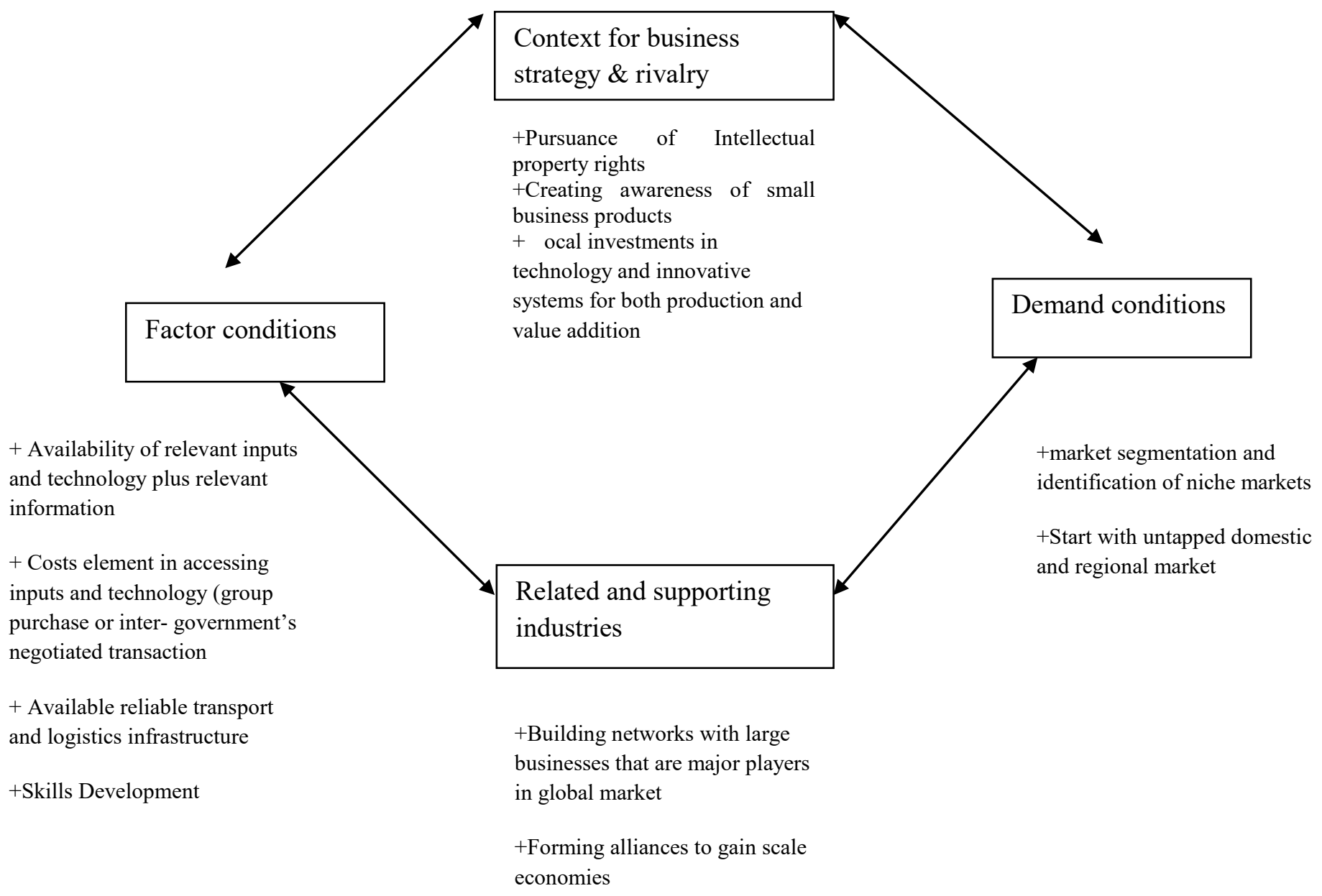


Potentially, globalization offer many opportunities to small businesses that position themselves in specific market niches. Individual businesses must choose to pursue specific innovation-based production, targeted to particular niche market segments. Tapping the unmet demand locally and within the regional economic block should naturally be the starting point so that opportunities are created to refine and perfect the products for international markets. Indeed, while studying $355 \mathrm{New}$ Zealand manufacturing export businesses, Hoang (1998) found out that export performance is significantly influenced by the choice of international marketing strategies which, in turn, is determined by a business's characteristics. Given the existing information asymmetries, small businesses must create information nodes though networks that are well connected internationally particularly with relatively larger businesses with wide knowledge of global markets. Networks are essential conduits of skills for quality improvement and valuation of products from the sector. In addition small businesses can form alliances with similarly local or foreign businesses.

Small businesses may learn by exporting but insufficient resources and an excessive perception of export risks may stifle efforts to participate in global markets. But small businesses may leverage the available local resources in addition to improvements made in infrastructure to minimize costs. Given the prime role of small businesses in employment generation and poverty reduction in developing countries, national governments are morally obliged to provide avail funding and logistical support in skills development, regional consulting and access to relevant information on technology and markets. Interventions that work on both the internal and external environment of a small business will strengthen its productivity and competitiveness and make it overcome the challenges of globalization.

\section{Reference}

Ahmad Tengku and Shamsudin Nasir (2008). "Market Liberalization and Its Relationship with Market Structure, Conduct and Performance of the Food Processing Industry in ASEAN Economies," Kuala Lumpur: APEC Secretariat

Archibugi D. and Pietrobelli C. (2002). "The Globalisation of Technology and Its Implications for Developing Countries, Windows of Opportunity or Further Burden?" Technological Forecasting \& Social Change 70 (2003) 861-883.

Brockhaus, R. (1982). Psychology of the Entrepreneur. New Yoke: Prentice Hall. Cornia Giovanni Andrea, (1999). "Liberalization, Globalization and Income Distribution," UNU World Institute for Development Economics Research (UNU/WIDER)

Goldin Ian (2010). "Globalization And Risks For Business: Implications of an Increasingly Interconnected World," University of Oxford's James Martin 21st Century School

Farazmand Ali (2002). "Privatization and Globalization: A Critical Analysis with Implications for Public Management Education and Training," International Review of Administrative Sciences, Vol. 68, No. 3 pp. 355-371.

Gerbner, G., Gross, L., Morgan, M., \& Signorielli, N. (1986). "Perspectives on media effects", in J. Bryant \& D. Zillmann (Eds.), Living with television. Hillsdale: Erlbaum.

Goodhue R. E., Rausser G. C. and Simon L.K. (1998). "Privatization, Market Liberalization and Learning in Transition Economies," American Journal of Agricultural Economics, Vol. 80/4, Nov. 1998, pp: 724-737

Greenaway, D., J. Gullstrand, and R. Kneller, (2008), "Surviving Globalization," Journal of International Economics, Vol. 74 (No.2), pp. 264-77.

Gürak (2003). "Hidden Costs of Technology Transfer," YK-Economic Review, June 2003

Haltiwanger John (2011). "Globalization and Economic Volatility," International Labour Organization and World Trade Organization Publications. Geneva Switzerland

Held, D., McGrew, A., Goldblatt, D., \& Perraton, J. (1999). Global transformations:

Politics, Economics, and Culture. Stanford, CA: Stanford University Press 
Hoang, B. Peter (1998). "A causal study of relationships between business characteristics, international marketing strategies, and export performance," Management International Review. Vol. 38, pp. 73-93.

Hussain I., Farooq Z., and Akhtar W. (2012). "SMEs Development and Failure Avoidance in Developing Countries through Public Private Partnership," African Journal of Business Management Vol. 6 (4), pp. 1581-1589

Hyden Goran (2003). "Experiences of Political Reform in Africa: Lessons for the Future," Bureau of International Cooperation, Hongkong Maco and Taiwan Academic Affairs Office, Chinese Academy of Social Sciences

KIPPRA, (2009). Kenya Economic Report 2009: Building a Globally Competitive Economy. Nairobi: Kenya Institute for Public Policy Research and Analysis

Lyons Jeffrey K. (2005). "Media Globalization and its Effect upon International Communities: Seeking a Communication Theory Perspective," Global Media Journal .Vol. 4, Issue 7

McClelland, D. (1961). The Achieving Society. Princeton : Van Nostrand

Ng'ang'a, J. C. (2008). "Determinants of Inter-firm Networks," KIPPRA Discussion Paper, DP No 89

Pierre-Andre Julien, (1996). "Globalization: Different Types of Small Business Behaviour," Journal of Entrepreneurship and Regional Development, 8 (1): 57-74.

Porter, M. E. (1990). The Competitive Advantage of Nations. New York: The Free Press. Republic of Kenya (2010). An Evaluation on Performance Contracting. Government Printer: Nairobi

Richard A. (1995). "Economic Pressures for Accountable Governance in the Middle East and North Africa" In: A. Norton (ed.), Civil Society and the Middle East, Vol. 1, Leiden, New York and Koln: E.J Brill.

Schumpter, J. (1934). The Theory of Economic Development. Cambridge: Harvard University Press.

Stephens, Thomas Kojo (2011), "Slow But Sure, Africa's Path to Democracy: [Bridled] Globalization, Education, and the Middle Class," Cornell Law School Graduate Student Papers. Paper No. 26.

Stohl, C. (2001). "Globalizing Organizational Communication," in F. Jablin \& L. Putnam (Eds.), The New Handbook Of Organizational Communication (pp. 323-375). Thousand Oaks, CA: Sage

Strelitz Larry (2004). "Against Cultural Essentialism: Media Reception among South African Youth," Media Culture Society, http://mcs.sagepub.com

United Nations Conference on Trade and Development (UNCTAD) (2004). Promoting the export Competitiveness of SMEs. mimeo

Wang Y._and Yin X. (2010). "Technology Transfer, Welfare, and Factor Prices," Working Paper Department of Economics, University of Windsor, Windsor, Ontario, Canada N9B 3P4 